Contents List available at RAZI Publishing Malaysian Journal of Sustainable Agriculture (MJSA)

Journal Homepage: http://www.razipublishing.com/journals/malaysian- journal- ofsustainable-agriculture-mjsa/

https://doi.org/10.26480/mjsa.01.2017.01.03
ISSN: 2521-2931 (Print)

ISSN: 2521-294X (Online)

\title{
Growth of Chenopodium quiona Wild under Naturally Salt Affected Soils
}

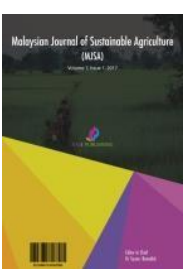

CrossMark

\author{
*Muhammad Arshadullah1, Muhammad Suhaib1, RaheelBaber1, Malik Usama2, Badar-uz-Zaman1, Imdad Ali Mahmood1 and \\ Syed Ishtiaq Hyder 1

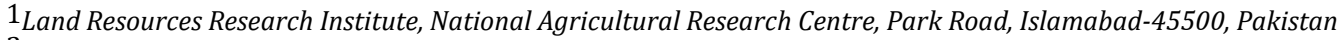 \\ 2Departmentof Soil \& Environmental Sciences, University of Haripur, KPK, Pakistan Correspondence Author;arshadullah1965@gmail.com
}

This is an open access article distributed under the Creative Commons Attribution License, which permits unrestricted use, distribution, and reproduction in any medium, provided the original work is properly cited

\section{ARTICLE DETAILS}

Article history:

Received 12 August 2016

Accepted 12 December 2016

Available online 20 January 2017

Keywords:

Salinity/ sodicity, Sodium Absorption Ratio, Electrical conductivity, halophyte, Salt tolerance and Quiona Growth

\section{ABSTRACT}

Salinity and sodicity is today one of the most shocking threat in the irrigated agriculture. Mostly this is an abiotic strain that influences germination and plant growth. Quinoa (Chenopodium quinoa Wild.) has garnered much attention in recent years because it is an excellent source of plant-based protein and is highly tolerance of soil salinity and sodicity. Protein content in most quinoa accessions has been reported to range from 12 to $17 \%$, depending on variety, environment, and input sit is traditionally called the mother of grains having the potential to habitat under high saline sodic conditions environment. The aim of the present protocol was to investigate the germination and growth of quinoa plant under different naturally salt affected soils. Quiona weeds were sown in different salt affected soils comparing with a normal soil. A pot experiment was planned using randomized complete block design with three replicates. Non- significant results regarding germination among different naturally salt affected and normal soils was determined However germination percentage was reduced to 66.8 $\%$ by soil 5 having $(S A R=37.2)$. In other words Quinoa seeds were germinated up to (SAR=37.2). Results of Quinoa plant height, fresh weight, and dry weight after two weeks were significantly affected by different naturally salt affected and normal soils. This study revealed the quiona growth was inversely proportional to the sodium absorption ratio. Reduction in growth parameters was associated with increasing trend of SAR due to the presence of excessive salts in plant tissues.

\section{INTRODUCTION}

Soil salinity and sodicity effect brutal harms in agriculture globally, and salt acceptance in crops is an enormously important attribute and a key hub of research. Injurious effects of high salinity and sodicity on crops are comprehensive and affect plants in several ways: alteration of metabolic processes, ion toxicity, drought stress, oxidative stress, nutritional disorders, membrane disorganization and reduction of cell division and expansion [1, 2. 3, 4, 5and 6]. Consequently development and survival of crop growth are retarded [7and 8]. Two major stresses affecting plants under salinity and sodicity are osmotic and ionic stresses. Osmotic stress, going on at once in the root medium on salts disclosure, can cause in inhibition of water uptake, cell expansion and lateral bud development and finally disturbs the plant growth as well as other physiological processes in plant [9].

Worldwide area under salt affected soils has been above 800 million hectares [10].1.5 million hectares of soils is salinized due to irrigation issue

and improper drainage in Turkey [11].Soil salinity and sodicity is the major abiotic stress that retards plant growth as well as losses badly the production nationally and globally [12,13and14] because most crop species are salt receptive glycophytes [2].

Salinity and sodicity are the mainly common ecological bullying to worldwide crop production, especially in arid and semi-arid climates, where land degradation, water shortage and population growth are already a major concern [ 9 and 15]. More than 800 million ha of land is saltaffected, which is over $6 \%$ of the world's land area and this area lowers the economics of the country [16]. Worldwide, salt-affected area is increasing as more and more land is ultimately claimed and irrigated for agricultural production to meet the exponential population growth and stagnant production can be increased with the best utilization of these salt- affected lands [17 and 18]. Due to untenable irrigation practices, about 1.6 million ha year-1 of irrigated lands become saline and go out of production due to secondary salinization and this quinoa crop can also tolerate drought stress [13]. The global annual cost of salinity is likely to be well over US\$12 billion [19] Hence, the future of agricultural production will ever more depend on our ability to grow plants on salt-affected and marginal lands using low (brackish or even saline) waters [20]. Keeping in view, the present study planned to investigate the best salt affected soil for the largely adaptation of $C$. quinoa.

\section{Material and Methods}

A pot experiment was carried out at NARC Islamabad to see the impact of salinity and sodicity on quinoa growth under different naturally normal and salt- affected soils. The soil samples were collected from different fields at $30 \mathrm{~cm}$ depth for the conductance of pot experiment. Soil samples were prepared for analysis of $\mathrm{pH}, \mathrm{ECe}$ $\mathrm{Na}, \mathrm{K}, \mathrm{Ca}+\mathrm{Mg}, \mathrm{Zn}, \mathrm{Cu}, \mathrm{Fe}, \mathrm{Mn}$ and soil texture. SAR of these soils was determined to qualify their identification according to salt- affected types. Randomized complete block design was applied with five different soils (Table1) with three replications. 350 grams soil was used in each pot. Six quinoa seeds were sown in each pot to see the germination, plant height fresh weight and dry weight Ionic concentration in Quinoa plant tissues under different naturally soil affected soils after two weeks were determined for quality. 
and salt- affected soils

\begin{tabular}{|c|c|c|c|c|c|}
\hline Properties & Soil $_{1}$ & Soil $_{2}$ & Soil $_{3}$ & Soil $_{4}$ & Soil ${ }_{5}$ \\
\hline $\mathrm{pH}$ & 7.43 & 8.05 & 9.29 & 8.77 & 9.51 \\
\hline $\mathrm{ECe}\left(\mathrm{dSm}^{-1}\right)$ & 1.2 & 5.5 & 1.98 & 1.5 & 1.43 \\
\hline SAR & 2.92 & 15.78 & 13.04 & 25.49 & 37.26 \\
\hline $\mathrm{Na}\left(\mathrm{mg} \mathrm{Kg}^{-1}\right)$ & 6.52 & 33.04 & 39.13 & 52 & 72.65 \\
\hline $\mathrm{K}\left(\mathrm{mg} \mathrm{Kg}^{-1}\right)$ & 5.90 & 7.82 & 5.51 & 5.51 & 5.90 \\
\hline Na: K & 1.10 & 4.23 & 7.10 & 9.44 & 12.31 \\
\hline $\begin{array}{l}\mathrm{Ca}+\mathrm{Mg} \quad \text { (mgKg- } \\
\text { 1) }\end{array}$ & 10 & 8.8 & 18 & 8.42 & 6.64 \\
\hline $\mathrm{Zn}\left(\mathrm{mg} \mathrm{Kg}^{-1}\right)$ & 13 & 1.65 & 0.8 & 0.3 & .004 \\
\hline $\mathrm{Cu}\left(\mathrm{mg} \mathrm{Kg}^{-1}\right)$ & 2.5 & 2.05 & 1.5 & 1.55 & .031 \\
\hline $\mathrm{Fe}\left(\mathrm{mg} \mathrm{Kg}^{-1}\right)$ & 0.45 & 5.65 & .116 & 2.4 & .052 \\
\hline $\mathrm{Mn}\left(\mathrm{mg} \mathrm{Kg}^{-1}\right)$ & 2.15 & 3 & 1.4 & 0.95 & 0.95 \\
\hline Texture & $\begin{array}{l}\text { Sandy } \\
\text { loam }\end{array}$ & $\begin{array}{l}\text { Silty } \\
\text { loam }\end{array}$ & loam & $\begin{array}{l}\text { Clay } \\
\text { loam }\end{array}$ & $\begin{array}{l}\text { Silty } \\
\text { loam }\end{array}$ \\
\hline
\end{tabular}

\section{Results and Discussion}

Non- significant results regarding germination among different naturally salt affected and normal soils were indicated in table-2. However germination percentage was reduced to $66.8 \%$ by soil 5 having (SAR=37.2) In other words Quinoa seeds were germinated up to (SAR=37.2). Tolerance of this plant at this increased SAR showed a remarkable utilization of salt affected lands for food security Lodging problem of quinoa seedlings was also noted. The lodging might be due to very thick and weak stem of quinoa seedlings.

Results of Quinoa plant height, fresh weight, and dry weight after two weeks were significantly affected by different naturally salt affected and normal soils (Table2). Growth of a plant is a very limiting factor in salt affected soils, So the significant increase in all growth parameters showed the well adaptation of this plant against the cancer of soil i.e.salinity/sodicity. The maximum plant height $(5.55 \mathrm{~cm})$ was attained at soil $_{1}\left(\mathrm{SAR}=2.92\right.$ ) followed by 4.50 and $4.50 \mathrm{~cm}$ in soil ${ }_{3}$ and soil ${ }_{2}$ respectively having SAR= 13.04 and 15.78 . These two figures are statistically at par with each other. Lowest plant height $(2.65 \mathrm{~cm})$ was attained by Soil 5 i.e. SAR= 37.26. This was confirmed that plant height was decreased as well as the SAR value was increased. Maximum fresh weight $\left(7.99 \mathrm{mg} \mathrm{plant}^{-1}\right)$ was gained by soil 1 (SAR=2.92) and it was statistically at par with $\left(7.52 \mathrm{mg}^{-1 a n t}{ }^{-}\right.$ 1) in soil ${ }_{2}$ having $S A R=15.78$. Similarly the maximum dry weight $(3.65 \mathrm{mg}$ plant $\left.^{-1}\right)$ was recorded in soil 1 (SAR=2.92) followed by $\left(3.30\right.$ mg plant $\left.^{-1}\right)$ in soil 2 having SAR=15.78. High concentration of salts especially sodium ions in the soil solution retards plant growth due to reduction in soil water osmotic potential and decreasing the growth rate at the end [21]. Further, more amounts of salt existing in the plant tissues will finally create toxic levels in the older transpiring leaves, causing premature senescence and reducing the assimilation, and consequently the growth[2 and 21].

Table 2: Growth of quinoa plant after two weeks under different natural soil conditions

\begin{tabular}{|l|l|l|l|l|}
\hline Soil type & Germination (\%) & Plant Height(cm) & Fresh Weight(mgplant $\left.{ }^{1}\right)$ & Dry Weight(mg plant $\left.{ }^{1}\right)$ \\
\hline Soil 1 & $91.5^{\text {Ns }}$ & $5.55 \mathrm{a}$ & $7.99 \mathrm{a}$ & $3.65 \mathrm{a}$ \\
\hline Soil2 & 88.5 & $4.50 \mathrm{~b}$ & $7.52 \mathrm{a}$ & $3.30 \mathrm{a}$ \\
\hline Soils & 83.7 & $4.80 \mathrm{~b}$ & $5.50 \mathrm{~b}$ & $2.55 \mathrm{~b}$ \\
\hline Soilt & 75.2 & $3.85 \mathrm{c}$ & $4.60 \mathrm{c}$ & $2.30 \mathrm{bc}$ \\
\hline Soils & 66.8 & $2.65 \mathrm{~d}$ & $3.40 \mathrm{~d}$ & $2.00 \mathrm{c}$ \\
\hline LSD & & 0.39 & 0.75 & 0.50 \\
\hline
\end{tabular}

Table 3: Ionic concentration in Quinoa plant tissues under different naturally soil affected soils after two weeks

\begin{tabular}{|l|l|l|l|l|l|l|l|}
\hline Soil type & Na (ppm) & $\mathrm{K}(\mathrm{ppm})$ & $\mathrm{N} \underline{\underline{\mathrm{a}}} \mathrm{K}$ & $\mathrm{Zn}(\mathrm{ppm})$ & $\mathrm{Cu}(\mathrm{ppm})$ & $\mathrm{Fe}(\mathrm{ppm})$ & $\mathrm{Mn}(\mathrm{ppm})$ \\
\hline Soil1 & $12.9 \mathrm{e}$ & $83.5 \mathrm{~b}$ & $0.15 \mathrm{e}$ & $8.6 \mathrm{a}$ & $1.15 \mathrm{Ns}$ & $62.5 \mathrm{a}$ & $2.5 \mathrm{Ns}$ \\
\hline Soil2 & $17.2 \mathrm{~d}$ & $91 \mathrm{a}$ & $0.2 \mathrm{~d}$ & $4.1 \mathrm{e}$ & 1.45 & $60.5 \mathrm{~b}$ & 2.5 \\
\hline Soils & $24.5 \mathrm{c}$ & $74.5 \mathrm{c}$ & $0.32 \mathrm{c}$ & $6.7 \mathrm{~b}$ & 1.49 & $36.5 \mathrm{c}$ & 2.8 \\
\hline Soil4 & $32.1 \mathrm{~b}$ & $69 \mathrm{~d}$ & $0.46 \mathrm{~b}$ & $4.95 \mathrm{~d}$ & 1.26 & $27.5 \mathrm{e}$ & 2.6 \\
\hline Soils & $37.2 \mathrm{a}$ & $65.5 \mathrm{~d}$ & $0.57 \mathrm{a}$ & $5.65 \mathrm{c}$ & 1.56 & $32.5 \mathrm{~d}$ & 3.1 \\
\hline
\end{tabular}

Results in table-3showed significant $\mathrm{Na}, \mathrm{K}, \mathrm{Na} / \mathrm{K}, \mathrm{Zn}$ and $\mathrm{Fe}$ concentration while $\mathrm{Cu}$ and $\mathrm{Mn}$ concentrations indicated nonsignificant behaviour in Quinoa plant tissues after two weeks under naturally normal and salt- affected soils.. Maximum Na (67.2 ppm) was recorded at soil swith SAR=37.2 and lowest (12.9 ppm) in the normal soil ${ }_{1}$. Na/K was maximum (0.57) at soil ${ }_{5}$ with $\mathrm{SAR}=37.2$ and the least 0.15 bythe normal soil 1 .Fe was recorded the maximum $(62.5 \mathrm{ppm})$ at the normal soil 1 and lowest $(12.9 \mathrm{ppm})$ in the normal soil $1 . \mathrm{Na} / \mathrm{K}$ was maximum (0.57) at soil ${ }_{5}$ with SAR=37.2 and the least 0.15 by soil swith $\mathrm{SAR}=37.2$ while $\mathrm{Cu}$ and $\mathrm{Mn}$ showed nonsignificant results. Maximum utilization of toxic salt improves soil health and better utilization of this marginal soil for medium salt tolerance crops.

\section{Conclusion}

In other words Quinoa seeds were germinated up to (SAR=37.2) Results of Quinoa plant height, fresh weight, and dry weight after two weeks were significantly affected by different naturally salt affected and normal soils. This study revealed the quiona growth was inversely proportional to the sodium absorption ratio. Reduction in growth parameters was associated with increasing trend of SAR due to the presence of excessive salts in plant tissues. Finally this plant can provide a great jump for the utilization of highly salt - affected lands in environmentally approach.

\section{References}

[1] Hasegawa PM, RA Bressan, JK Zhu, HJ ,Bohnert,2000 Plant cellular and molecular responses to high salinity. Annual Review of Plant Physiology and Plant Molecular Biology; 51:463 499.

[2] Munns, R., 2002. Comparative physiology of salt and water stress. Plant Cell Environ. 25, 239-250.

[3] Muscolo A, M Sidari, C Santonoceto, U Anastasi, G Preiti 2007. Response of four genotypes of lentil to salt stress conditions. Seed Science and Technology 35:497-503.

[4] Muscolo A, MR Panuccio,A Heshel. 2013. Ecophysiology of Pennisetum clandestinum: a valuable salt toleran grass. Environmental and Experimental Botany 92:55-63.

[5] Zhu JK. 2007. Plant salt stress. In: O'Daly A, ed Encyclopedia of

life sciences. Chichester: John Wiley \& Sons, Ltd, 1-3.

[6] Sidari M, C Santonoceto, UAnastasi, GPreiti, AMuscolo. 2008. Variations in four genotypes of lentil under NaCl-salinity stress. American Journal of Agriculture and Biological Science 3:410-416.

[7] Muscolo A, M Sidari, MRPanuccio, C Santonoceto, F Orsini, S DePascale. 2011. Plant responses in saline and semi arid environments: an overview. The European Journal of Plant Science and Biotechnology 5:1- 11.

[8] Schleiff Uand AMuscolo. 2011. Fresh look at plant salt tolerance as affected by dynamics at the soil/root-interface using Leek and Rape as model crops. The European Journal of Plant Science and Biotechnology 5:27-32.

[9] Munns R, M Tester. 2008. Mechanisms of salinity tolerance. Annual Review of Plant Biology 59:651-681.

[10] Rengasamy, P. 2010. Soil processes affecting crop production in salt-affected soils. Functional Plant Biology, 37: 613620

[11] FAO, 2014. Irrigation in the Middle East region in figures- AQUASTAT Survey 2008.

http://www.fao.org/nr/water/aquastat/countries regions/tur/T 
[12]Pitman,M.G.,andALäuchli,.,2002..."Globalimpactofsalinityandagri cultur alecosystems,"inSalinity:Environment-PlantsMolecules,edsA.LäuchliandU.Lüt(Netherlands:Springer),3-20.

[13] Tanji KK 2002.Salinity in the soil environment. In: Läuchli A. Lüttge U (ed) Salinity: environment- plants- molecules. Kluwer Academic Publishers, Dordrecht, pp 21-25

[14] Hu YC and U Schmidhalter,2005. Drought and salinity: a comparison of their effects on mineral nutrition of plants' Plant Nutr Soil Sci 168:541-549

[15] Geissler N, S Hussin, HWKoyro, 2010.Elevated atmospheric CO2 concentration enhances salinity tolerance in Aster tripoliumL Planta 231:583-594

[16] Rengasamy P 2006. World salinization with emphasis on Australia. J Exp Bot 57:1017-23

[17] Lambers H 2003. Dry land salinity: A key environmental issue in southern AustraliaIntroduction. Plant Soil 257:VVii

[18] Munns R., 2005. Genes and salt tolerance: bringing them together. New Phytol 167: 645-63

[19] Qadir M, A Tubeileh, J Akhtar,ALarbi, PS Minhas, MA Khan 2008.Productivity enhancement of salt-affected environments through crop diversification. Land Degradation Development. 19:429453

[20] Rozema J and TJ Flowers, 2008.Crops for a salinized world.

Science 322:1478-1480

[21] Munns, R., 2009: Strategies for crop improvement in saline soils. In: M. Ashraf, M. Ozturk, and H. R. Athar, eds. Salinity and Water Stress: Improving Crop Efficiency, pp. 99-110. Springer, The Netherlands. 